\title{
AN ANALYSIS OF STUDENTS' ABILITY IN USING SUB-ORDINATE CONJUNCTION IN SENTENCE WRITING OF THE GRADE XII STUDENTS OF SMA N 2 METRO ACADEMIC YEAR 2013/2014
}

\author{
Bambang Eko Siagianto \\ STBA YUNISLA Bandarlampung
}

\begin{abstract}
Sub-ordinate conjunction is very confusing to comprehend by students. In using subordinate conjunction, students usually had errors. The purpose of this research to analyze whether or not the students are able to use sub-ordinate conjunction in sentence writing, to classify kinds of sub-ordinate conjunction that was often misused by students in sentence writing The research was done at the grade XII of SMA N 2 Metro in second semester of the academic year 2013/2014. The predicted research findings are; the students cannot divide or difference the type of sub-ordinate conjunction well, and they often errors using it in sentences. The result of the students test in using sub-ordinate conjunction in sentence writing proves that most of the students at the grade XII of SMA N 2 Metro used the list of words "after, then, when, because" on their sentence writing. The students found these words easier to be used as conjunction especially sub-ordinate conjunction in their sentence writing than other conjunction. While, for other list of words doesn't used by the students because the students cannot adapted the words in their sentence writing. The most familiar sub-ordinate conjunction seems to be "before and since" (each of them is gained by 22 students $=91,6 \%$ ), but the students are unfamiliar with the other words in sub-ordinate conjunction mainly "till and unless" (each of the is gained by 13 students $=54,1 \%$ ). The other sub-ordinate conjunctions are quite familiar for them.
\end{abstract}

Key Words: conjunction, sentence writing, sub-ordinate conjunction

\section{Introduction}

A conjunction, by definition, is a word that joins words, phrases, or clause (Treanor; 1967:292). Furthermore, $\mathrm{K}$ and $\mathrm{J}$ Cooper $(1979: 159)$ state that a conjunction is a word which merely join together sentences, and sometimes words. In addition, the Oxford Dictionary (edition 2005:740) describes conjunction is one of the part speech; a word used to connect clauses or to coordinate words in the same clauses.

According to Treanor (1997:292) there are three kinds of conjunctions. One of them is subordinate conjunction. Sub-ordinate conjunctions are words or phrases that connect a dependent clause or adjective or adverbial phrase to an independent clause. The dependent clauses provide context and description for the independent clause; in short, it adds information that is not the direct focus of the sentence but is important in adding time, place, or reasons to the sentence. Sub-ordinate conjunction also called coordinators, are conjunction that introduce a dependent clause. A sub-ordinate conjunction joins a sub-ordinate clause (sub-ordinate means "in the lower rank") since sub-ordinate clause depends upon a principal clause. It is lower and therefore requires a sub-ordinate conjunction. Common sub-ordinate conjunctions: after; before; though; although; until; till; since; as; unless; then; that; when; where; while; because. 
Based on the result of research conducted by Fitriyati (1995) in one SMA in Bandar Lampung, it is found that most of the students get difficulties in organizing the word into sentence, namely the idea which is to be expressed, is not clear.

Similarly, in the previous research be the researcher himself found that most students of Senior High School, especially students of SMA N 2 Metro, get difficulty in expressing their idea in written form. They have low ability in writing sentence. They have difficulties to express their idea, especially in using subordinate conjunction. The finding of that research is that the students there often make errors and make mistakes in their writing sentence.

The data of the previous research are described as the following. There are $20 \%$ of students can use conjunction quite properly but $80 \%$ of them seemed to get problem in using conjunction in sentence properly.

Cooper (1979) states that the word merely joins together sentences and sometimes words are joined by conjunction. Conjunction, as it is defined in oxford dictionary (1991), is a part of speech, a word used to connect clause or to coordinate word in the same clauses. Conjunction is one of elements in structure. It is actually as important as other elements of structure such as noun, preposition, pronoun, adverb, adjective, etc.

Based on the explanation above, it is clear that conjunction is one element of structure which is important to increase the students' ability in sentence writing. In this occation, the researcher would like to know further about the students' ability in applying sub-ordinate conjunction in writing sentence.

\subsection{Problem Identification}

Based on the background of problem above, the researcher identifies some problems as the followings:

1) Most of the students find the difficulties in organizing words into sentence.

2) Most of the students have low ability in writing sentence.

3) Most of the students often make errors in using subordinate conjunction.

\subsection{Problem Formulation}

Considering the limitation of the problems above, in this research the researcher formulates the problem: Which of sub-ordinate conjunctions are mostly misused by the students in writing the sentence?

\subsection{Research Benefit}

Theoretically, this research was intended to inform whether or not the result is relevant to the previous theory about sub-ordinate conjunction in sentence writing. On the other hand, practically, the result of this research can be used as an input and remedial action for the students in using sub-ordinate conjunction in sentence writing.

\subsection{Research Objective}

The purpose of this research is to find out what kind of sub-ordinate conjunction which is frequently misused by students in writing sentence. 


\subsection{Research Scope}

This research is about students' ability in using sub-ordinate conjunction in writing sentence of the grade XII of SMA N 2 Metro. The population of this research is grade XII. The sample of this research is one class, which was taken randomly. In this case, the researcher analyzes how the students make sentence by using teacher given sub-ordinate conjunction.

\section{Theoretical Framework}

\subsection{An Overview on the Result of a Previous Research}

There are two previous research result discussed to initiate the idea in this research. The first research is the one previously conducted by Hermanto, the second one is the research conducted by Siagiyanto.

The first previous research result which is overviewed in this occasion is a research by Hermanto. He finds that the students' problems in using correlative conjunction is caused by the lack of comprehension in the kinds of conjunction in sentence writing. The students may know the conjunction, but in using the conjunction the students have low ability and often make a mistake in using the conjunction in sentence writing. The students tend to make an error and mistakes in using conjunction correctly.

On the other part, Siagiyanto (2012) with his research found that $50 \%$ of the students still get problem in using sub-ordinate conjunction. The misuse of the sub-ordinate conjunction is similarly to any conjunction. It means that it is not dominated by a particular conjunction.

In the research, the researcher wants to know further whether such misused is also happen to different grade of students from diffe

school. This is a qualitative resea..... According to Jacob in Salinger (1989: 118) qualitative method is originally developed from the methodologies of field anthropologies and sociologies concerned with study human behavior within the context in which that behavior could occur naturally and in which the role of the researcher could not affect the normal behavior of the subjects. Salinger (1989: 118) say , “...qualitative are concerned with providing description of phenomena that occur naturally, without the intervention of an experiment or an artificially contrived".

Through qualitative research model the writer might be able to collect the data to answer the problem above because qualitative model can facilitate to know both the process of using conjunction in sentence writing and the result. In this research, the writer used interview and test as data collecting techniques and instrument.

\subsection{A Review on Theory}

There are some theories needed as references in this research. Some of them are theory about the concept of sentence, and concept of conjunction.

\section{1) Concept of Sentence}

Sentence and word are two grammatical units that are 
recognized in the folk of linguistics. Sentence and word are not so sharply set off from one another; they are no different in kind; both are units in the grammar (Halliday, 1994).

In line with Halliday, Wiener (1981) defines, "A sentence is a group of words containing a subject and a predicate and expressing a complete thought. A sentence is a group of words naming a subject and telling something about that subject"

\section{2) Concept of Conjunction}

A conjunction is a word that joins words, phrases, or clause (Treanor; 1967:292). Furthermore, K and J Cooper (1979:159) state that a conjunction is a word which merely join together sentences, and sometimes words. In addition, the Oxford Dictionary (edition 2005:7grade XII0) describes conjunction is one of the part speech; a word used to connect clauses or to coordinate words in the same clauses.

According to Treanor (1997:292) there are three kinds of conjunctions. They are:

1. Coordinate conjunction

2. Sub-ordinate conjunction

3. Correlative conjunction

In this case, the writer only takes one of conjunctions, which are "subordinate conjunction". A subordinate conjunction joins a subordinate clause (subordinate means "in the lower rank"). Since subordinate clause upon a principle clause, it is lower and therefore requires a subordinate conjunction.

Based on Encyclopedia, a conjunction is a part of speech that connects two words, phrases or clauses together. This definition may overlap with that of other parts of speech so what constitutes a "conjunction" should be defined for each language. In general, a conjunction is an invariable grammatical particle, and it may or may not stand between the items it conjoins. The definition can also be extended to idiomatic phrases that behave as a unit with the same function as a single-word conjunction (as well as, provided that, etc.). Conjunction must be carefully distinguished from relative pronouns, relative adverbs, and preposition which are also connecting words.

\section{2) Classification Conjunction}

According to Treanor (1979:292) there are three kinds of conjunction:

a) Coordinate Conjunction

Coordinate conjunctions, also called coordinators, are conjunctions that join two or more items of equal syntactic importance. The mnemonic acronym fan boys should not be used to remember the coordinators. It is often stated that the seven words for, and, nor, but, or, yet, and so are the only coordinate conjunction; however, for, so, and yet are not coordinate conjunctions, and various others are used, including whilst and now. A coordinate conjunction joins words, phrases, or clauses of equal rank. Coordinate means "in the same rank".

Joining words : meat and potatoes Phrases : in sickness and in health 
Clause : the radio works but the television is broken.

b) Sub-ordinate Conjunction

Sub-ordinate conjunctions are words or phrases that connect a dependent clause or adjective or adverbial phrase to an independent clause. The dependent clauses provide context and description for the independent clause; in short, it adds information that is not the direct focus of the sentence but is important in adding time, place, or reasons to the sentence. Sub-ordinate conjunction also called coordinators, are conjunction that introduce a dependent clause. A sub-ordinate conjunction joins a sub-ordinate clause (sub-ordinate means "in the lower rank") since sub-ordinate clause depends upon a principal clause. It is lower and therefore requires a sub-ordinate conjunction.

Common sub-ordinate conjunctions: after; before; though; although; until; till; since; as; unless; then; that; when; where; while; because.

c) Compound Sub-ordinate Conjunction

Provide that; As long as; In as much as; In order that; So that; Just as; Even though; Not withstanding

Example of sub-ordinate conjunction:

"Unless you save part of your allowances you will lack of money for the festival at the rink".

The sub-ordinate conjunction "unless" joins the sub-ordinate clause unless you save part of your allowances to the principal clauses to will lack of money for the festival at the rink.

"The cowhand continued to search for missing calf, even though darkness was imminent".

The conjunction "even though" joins the sub-ordinate clause to the principal clause. It is therefore the sub-ordinate conjunction.

"After the shows was over, the adolescent swamped a nearby snack bar"

After, introduces a sub-ordinate clause and "therefore", a preposition.

d) Correlative Conjunction

Correlative conjunction is pairs of conjunctions that work together to co-ordinate two items.

The examples of common coordinate correlative:

a. Both... and

b. But also

c. Either

d. Not only

e. Neither...nor

f. Whether

Phrases or clauses using coordinate correlatives:

a. Both a lower temperature and stronger wing.

b. Neither asks a question nor often an answer.

c. Not only is he handsome but he is also brilliant.

3) Common Sub-ordinate Correlatives:

1. Although yet

2. Even though...still

3. If...then

4. Since...therefore

Since there are many kinds of conjunctions, the writer focus only 
on thee sub-ordinate conjunctions since the scope of this research is at the second year of SMA students which learn the conjunction only in the sub-ordinate conjunction area.

\section{4) Conjunction in Sentence}

In communication, whether someone uses oral written form, it is important to know how apply the right structure in the right situation. Bott (1978:181) says that writing ability in proportional to knowledge the structure. Most of English students as a foreign language would be excellent writer. Basri (1998:181) states that structure is very important in writing. Thus, referring to the statement above, in order to be able to write in English, the students have to master some aspects of writing.

Here are the examples of subordinate conjunction in sentence:

Gold, is precious is prized for two important characteristics. First of all, gold has a lustrous beauty that is resistant to corrosion. Therefore, it is suitable for jewelry, coins, and ornamental purposes. Gold never needed to be polished and will remain beautiful forever. For example, a Macedonian coin remains as untarnished characteristic of gold is its usefulness to industry and science. For many year, it has been used in hundred of industrial applications. The most recent used of gold is in astronaut suit. In conclusion, gold is treasured not only for its beauty, but also for its utility (Oshima and Hogue).

\section{Research Method}

3.1 Design of the Research
The researcher uses descriptive method. According to Leedy (1997) descriptive method is a simply look with intense accuracy at the phenomena of the moment and describes precisely of what the researcher sees. The researchers start out with the assumption that access to reality (given on socially constructed) is only through social construction such as language, consciousness and shared meaning. Interpretive research does not predefine dependent and independent variable, but focuses on the full complexity of human sense making as the situation emerges.

Considering the statement above, the writer only shows the phenomena of the research at the moment of certain time. In this case, the writer will give the test and will analyze the data of the research, furthermore, this method is suitable for the object of this research, and this is to describe the students' ability in using sub-ordinate conjunction in sentence writing. Dealing with the statement above, the writer will analyze the subordinate conjunction in sentence writing made by the students. To know the students' opinions and responses on activities the researcher does an interview to the students this research, the researcher will use the following procedure:

1. Determining the subject,

2. Preparing appropriate materials for curriculum and suitable for the students,

3. Coming to class in order to make test when learning process is being conducted,

4. Analyzing the data, and 
5. Making the report of the finding.

\subsection{Research Variable}

Thdere are many theories

which talk about variable of a research. In general, they mention that there are two major types of variable namely independent and dependent variables. About dependent variable, Setiyadi (2006:106) states that dependent variable is the main variable in a research. And independent variable is a variable in a research is being caused or have function to influence dependent variable.

This research consists of two variables: they are dependent variable and independent variable. Dependent variable is the variable which the researcher observes and measures to determine the effect of the independent variable.

Independent variable is the variable which is selected, manipulated and measured by the research. There are two variables in this research; they are sub-ordinate conjunction as the independent variable and students' ability in writing the sentence is dependent variable.

The description as follows:

1. The independent variable of the research is sub-ordinate conjunction $(\mathrm{X})$.

2. The dependent of the research is Students' Ability in writing the sentence (Y).

\subsection{Research Population and Sample In this research, the} populations are grade XII students of
SMA N 2 Metro. The sample of the research is one class of the grade XII which was taken clustery by using random technique.

\subsection{Research Instrument and Data Collecting Technique \\ Research instrument is test.} The researcher asked the students to make sentences in English by applying provided sub-ordinate conjunction. The result of subordinate conjunction used by the students can be seen in the format as attached in gthe end of thsi part.

This test is intended as the main source of the data. The writer includes the result of the test made by the students. In doing the test, the writer asks the students to make sentences each consists of one subordinate conjunction.

\subsection{Data Analysis}

In order to analyze the data in qualitative research there are some steps. According to Moleong (1990:198), there are four steps in analyzing and interpreting the data. Therefore, the researcher follows those steps in this research:

1. Making the abstraction of all collected data to be treated in one unit.

The researcher interprets all data available (from observation and interview) by selecting them into an abstraction. In this step, he selects the data in order to keep them relevant to the research question.

2. Arranging all collected data by uniting data. 
Table 3.1: The Individual Ability in Using Sub-ordinate Conjunction.

\begin{tabular}{|c|c|c|c|c|c|c|c|c|c|c|c|c|c|c|c|c|}
\hline \multirow[b]{2}{*}{ No } & \multirow[b]{2}{*}{ Students of Grade XII } & \multicolumn{15}{|c|}{ Sub-ordinate Conjunction } \\
\hline & & $\stackrel{5}{4}$ & $\begin{array}{l}0 \\
0 \\
0 \\
0\end{array}$ & F & 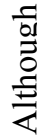 & 吾 & $\overline{\bar{F}}$ & & & 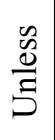 & $\underset{\mathbb{E}}{\stackrel{E}{E}}$ & $\underset{E}{E}$ & $\sum_{3}^{\bar{d}}$ & $\frac{\mathscr{D}}{\frac{0}{3}}$ & $\frac{0}{\frac{0}{3}}$ & 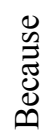 \\
\hline 1 & Abdul Munir & $\sqrt{ }$ & $\sqrt{ }$ & $\mathrm{X}$ & $\mathrm{X}$ & $\sqrt{ }$ & $\mathrm{X}$ & 1 & & $\mathrm{X}$ & $\sqrt{ }$ & $\sqrt{ }$ & $\mathrm{X}$ & $\sqrt{ }$ & $\mathrm{X}$ & $\sqrt{ }$ \\
\hline 2 & Adinda Choirul U. & $\mathrm{X}$ & $\sqrt{ }$ & $\sqrt{ }$ & $\sqrt{ }$ & $\mathrm{X}$ & 1 & 1 & & $\mathrm{X}$ & $\sqrt{ }$ & $\mathrm{X}$ & $\sqrt{ }$ & $\sqrt{ }$ & $\sqrt{ }$ & \\
\hline 3 & Avinka Rahmanda P & $\sqrt{ }$ & $\sqrt{ }$ & $\mathrm{X}$ & $\sqrt{ }$ & $\sqrt{ }$ & $X$ & 1 & & $\sqrt{ }$ & $\mathrm{X}$ & $\sqrt{ }$ & $\sqrt{ }$ & $\sqrt{ }$ & $\sqrt{ }$ & $\sqrt{ }$ \\
\hline 4 & Budi Prasetyo & $\mathrm{X}$ & $\sqrt{ }$ & $\mathrm{X}$ & $\sqrt{ }$ & $\sqrt{ }$ & $\sqrt{ }$ & 1 & & $\mathrm{X}$ & $\sqrt{ }$ & $\sqrt{ }$ & $\sqrt{ }$ & $\mathrm{X}$ & $\mathrm{X}$ & $\mathrm{X}$ \\
\hline 5 & Dwi Erowati & $\sqrt{ }$ & $\sqrt{ }$ & $\mathrm{X}$ & $\sqrt{ }$ & $\sqrt{ }$ & $\sqrt{ }$ & 1 & & $\sqrt{ }$ & $\sqrt{ }$ & $\mathrm{X}$ & $\sqrt{ }$ & $\sqrt{ }$ & $\mathrm{X}$ & $\sqrt{ }$ \\
\hline 6 & Dwi Ningrum & $\sqrt{ }$ & $\sqrt{ }$ & $\sqrt{ }$ & $X$ & $\mathrm{X}$ & $X$ & 1 & & $\mathrm{X}$ & $\sqrt{ }$ & $\sqrt{ }$ & $\sqrt{ }$ & $\sqrt{ }$ & $\sqrt{ }$ & $\sqrt{ }$ \\
\hline 7 & Feni Aulia R & $\mathrm{X}$ & $\sqrt{ }$ & $\sqrt{ }$ & $\sqrt{ }$ & $\sqrt{ }$ & $\mathrm{X}$ & 1 & & $\sqrt{ }$ & $\sqrt{ }$ & $\mathrm{X}$ & $\mathrm{X}$ & $\sqrt{ }$ & $\mathrm{X}$ & $\sqrt{ }$ \\
\hline 8 & Fitriana & $\sqrt{ }$ & $\sqrt{ }$ & $\sqrt{ }$ & $\sqrt{ }$ & $\sqrt{ }$ & $\sqrt{ }$ & 1 & & $\sqrt{ }$ & $\sqrt{ }$ & $\sqrt{ }$ & $\sqrt{ }$ & $\sqrt{ }$ & $\sqrt{ }$ & $\sqrt{ }$ \\
\hline 9 & Linda Puspita Sari & $\sqrt{ }$ & $\sqrt{ }$ & $\sqrt{ }$ & $\sqrt{ }$ & $\sqrt{ }$ & $\sqrt{ }$ & 1 & & $\sqrt{ }$ & $\sqrt{ }$ & $\mathrm{X}$ & $\sqrt{ }$ & $\sqrt{ }$ & $\sqrt{ }$ & $\sqrt{ }$ \\
\hline 10 & Linda Rahmawati & $\sqrt{ }$ & $\sqrt{ }$ & $\sqrt{ }$ & $\sqrt{ }$ & $\sqrt{ }$ & $V$ & 1 & & $\sqrt{ }$ & $\sqrt{ }$ & $\sqrt{ }$ & $\sqrt{ }$ & $\sqrt{ }$ & $\sqrt{ }$ & $\sqrt{ }$ \\
\hline 11 & Loveca Putri & $\mathrm{X}$ & $\sqrt{ }$ & $\sqrt{ }$ & $\sqrt{ }$ & $\mathrm{X}$ & $\mathrm{X}$ & 1 & & $\sqrt{ }$ & $\sqrt{ }$ & $\sqrt{ }$ & $\sqrt{ }$ & $\sqrt{ }$ & $\sqrt{ }$ & $\mathrm{X}$ \\
\hline 12 & Meri Anisa Putri & $\sqrt{ }$ & $\sqrt{ }$ & $\mathrm{X}$ & $\mathrm{X}$ & $\sqrt{ }$ & $\sqrt{1}$ & 1 & & $\mathrm{X}$ & $\sqrt{ }$ & $\sqrt{ }$ & $\mathrm{X}$ & $\sqrt{ }$ & $\sqrt{ }$ & $\sqrt{ }$ \\
\hline 13 & Miftah Hurahmah & $\mathrm{X}$ & $\sqrt{ }$ & $\sqrt{ }$ & $\sqrt{ }$ & $\sqrt{ }$ & $X$ & 1 & & $\sqrt{ }$ & $\sqrt{ }$ & $\sqrt{ }$ & $\sqrt{ }$ & $\sqrt{ }$ & $\sqrt{ }$ & $\sqrt{ }$ \\
\hline 14 & Minatus Syarof & $\sqrt{ }$ & $\sqrt{ }$ & $\mathrm{X}$ & $\sqrt{ }$ & $\sqrt{ }$ & $\sqrt{ }$ & 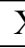 & & $\mathrm{X}$ & $\sqrt{ }$ & $\mathrm{X}$ & $\sqrt{ }$ & $\sqrt{ }$ & $\sqrt{ }$ & $\mathrm{X}$ \\
\hline 15 & Moko Hadi Sasmito & $\mathrm{X}$ & $\sqrt{ }$ & $\sqrt{ }$ & $\sqrt{ }$ & $\sqrt{ }$ & $\sqrt{ }$ & 1 & & $\sqrt{ }$ & $\sqrt{ }$ & $\sqrt{ }$ & $\mathrm{X}$ & $\mathrm{X}$ & $\sqrt{ }$ & $\sqrt{ }$ \\
\hline 16 & Nova Nur Aziyah & $\mathrm{X}$ & $\mathrm{X}$ & $\sqrt{ }$ & $\sqrt{ }$ & $\sqrt{ }$ & $X$ & 1 & & $\mathrm{X}$ & $\mathrm{X}$ & $\sqrt{ }$ & $\sqrt{ }$ & $\sqrt{ }$ & $\mathrm{X}$ & $\sqrt{ }$ \\
\hline 17 & Nurmalita Angga D & $\sqrt{ }$ & $\sqrt{ }$ & $\mathrm{X}$ & $\mathrm{X}$ & $\sqrt{ }$ & $\sqrt{ }$ & 1 & & $\mathrm{X}$ & $\sqrt{ }$ & $\sqrt{ }$ & $\sqrt{ }$ & $\sqrt{ }$ & $\sqrt{ }$ & $\sqrt{ }$ \\
\hline 18 & Ria Mardiana & $\sqrt{ }$ & $\sqrt{ }$ & $\mathrm{X}$ & $\sqrt{ }$ & $\sqrt{ }$ & $X$ & $I$ & & $\sqrt{ }$ & $\sqrt{ }$ & $\mathrm{X}$ & $\mathrm{X}$ & $\sqrt{ }$ & $\mathrm{X}$ & $\sqrt{ }$ \\
\hline 19 & Rosela Febtriandani & $X$ & $\sqrt{ }$ & $\sqrt{ }$ & $\sqrt{ }$ & $\sqrt{ }$ & $\sqrt{1}$ & 1 & & $\mathrm{X}$ & $\sqrt{ }$ & $\sqrt{ }$ & $\mathrm{X}$ & $\sqrt{ }$ & $\sqrt{ }$ & $\sqrt{ }$ \\
\hline 20 & Sapta Nurmala Sari & $\sqrt{ }$ & $\sqrt{ }$ & $\sqrt{ }$ & $\sqrt{ }$ & $\sqrt{ }$ & $\mathrm{X}$ & 1 & & $\sqrt{ }$ & $\mathrm{X}$ & $\sqrt{ }$ & $\sqrt{ }$ & $\sqrt{ }$ & $\mathrm{X}$ & $\mathrm{X}$ \\
\hline 21 & Seli Endarwati & $\mathrm{X}$ & $\sqrt{ }$ & $\mathrm{X}$ & $\sqrt{ }$ & $\mathrm{X}$ & 1 & 1 & & $\mathrm{X}$ & $\mathrm{X}$ & $\mathrm{X}$ & $\sqrt{ }$ & $\sqrt{ }$ & $\sqrt{ }$ & $\sqrt{ }$ \\
\hline 22 & Tika Noviaba Sari & $\sqrt{ }$ & $\mathrm{X}$ & $\sqrt{ }$ & $\mathrm{X}$ & $\sqrt{ }$ & $X$ & 1 & & $\sqrt{ }$ & $\sqrt{ }$ & $\sqrt{ }$ & $\sqrt{ }$ & $\sqrt{ }$ & $X$ & $\sqrt{ }$ \\
\hline 23 & Wendy Noviance & $\sqrt{ }$ & $\sqrt{ }$ & $\mathrm{X}$ & $\sqrt{ }$ & $\sqrt{ }$ & $X$ & 1 & & $\mathrm{X}$ & $\sqrt{ }$ & $\sqrt{ }$ & $\mathrm{X}$ & $\mathrm{X}$ & $\sqrt{ }$ & $\sqrt{ }$ \\
\hline 24 & Wulanda Reski N. & $\sqrt{ }$ & $\sqrt{ }$ & $\sqrt{ }$ & $\sqrt{ }$ & $\sqrt{ }$ & 1 & 1 & & $\sqrt{ }$ & $X$ & $\sqrt{ }$ & $\sqrt{ }$ & $\sqrt{ }$ & $\sqrt{ }$ & $\sqrt{ }$ \\
\hline \multicolumn{2}{|r|}{ Total } & 15 & $\begin{array}{l}2 \\
2 \\
\end{array}$ & $\begin{array}{l}1 \\
4 \\
\end{array}$ & $\begin{array}{l}1 \\
9 \\
\end{array}$ & $\begin{array}{l}2 \\
0 \\
\end{array}$ & 3 & 2 & & $\begin{array}{l}1 \\
3 \\
\end{array}$ & 19 & $\begin{array}{l}1 \\
7 \\
\end{array}$ & $\begin{array}{l}1 \\
7 \\
\end{array}$ & $\begin{array}{l}2 \\
1 \\
\end{array}$ & 16 & 20 \\
\hline & Percentage $(\%)$ & v & $\begin{array}{l}\stackrel{\circ}{\bullet} \\
\stackrel{\sigma}{\sigma}\end{array}$ & $\begin{array}{l}\mathcal{N} \\
\infty \\
\omega\end{array}$ & $\stackrel{\bullet}{\circ}$ & $\underset{\omega}{\infty}$ & 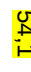 & 0 & & 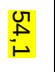 & $\stackrel{\bullet}{\circ}$ & $\underset{\infty}{0}$ & $\begin{array}{c}\text { Dै } \\
\infty\end{array}$ & $\begin{array}{l}\stackrel{\infty}{-} \\
\text { iv }\end{array}$ & $\begin{array}{l}\text { के } \\
\circ\end{array}$ & $\underset{\omega}{\infty}$ \\
\hline
\end{tabular}

The researcher identifies the data into unity. Its means that he pays attention to the term the students used, to distinct the activities in the process.

3. Categorizing the grouped data by giving code for each data.

The researcher arranges the data according to the determined criteria for each data based on the objective of the research for discussion.

\section{Interpreting data into substantive theory.}

The researcher takes conclusion. Then, as the final steps, he interprets the data into substantive theory about the research of students' ability in using sub-ordinate conjunction in sentence writing. 


\section{Result And Discussion}

\subsection{Result}

This research was conducted with the objectives of analyzing the sub-ordinate conjunction in sentence writing made by students of SMA N 2 grade XII Metro.

In analyzing the use of conjunction, the writer limited his point of view at the usage of common sub-ordinate conjunction, such as after, although, as because, before, since, that, then, unless, when, till, until, while, and though. This was in order to correlate with the scope of the research. Thus, the writer administered the test for the students to know how far the students' ability in using subordinate conjunction.

In administering the test, the researcher just provide sub-ordinate conjunction, the students are requested to develop sentences freely but consists of the intended subordinate conjunction. The researcher, assisted by the teacher, administered the test to the grade XII students at SMA N grade XII Metro, especially the sample class namely XII IPA4.

It has been stated on the previous sentence, that the writer limited his research on the subordinate conjunction only. Previously reason, they were kinds of conjunction in sentence writing such as Coordinate Conjunction, Correlative Conjunction, and Subordinate Conjunction. A sub-ordinate conjunction joins a sub-ordinate clause (Sub-ordinate means "in the lower rank"). Since sub-ordinate clause depend upon a principal clause, it was lower and therefore require a sub-ordinate conjunction.

Having seen the result of the students' test on sentence writing, the writer would like to stress some common sub-ordinate conjunction the students usually used. It was drawn into a list of table below.

Most of the students at the grade XII of SMA N 2 Metro used the list of words "after, then, when, because" on their sentence writing. The students found these words easier to be used as conjunction especially sub-ordinate conjunction in their sentence writing than other conjunction. While, for other list of words doesn't used by the students because the students cannot adapted the words in their sentence writing. The most familiar sub-ordinate conjunction seems to be "before and since" (each of them is gained by 22 students $=91,6 \%$ ), but the students are unfamiliar with the other words in sub-ordinate conjunction mainly "till and unless" (each of the is gained by 13 students $=54,1 \%$ ). The other sub-ordinate conjunctions are quite familiar for them.

\subsubsection{Students' Problems in Using Sub-ordinate Conjunction in Sentence Writing}

The problems could be analyzed while they were trying to express their ideas, more specially in using sub-ordinate conjunction. It seemed that the students got confuse in using the list of sub-ordinate conjunction and how to arrange it into a sentence. Thus, analyzing from the result of the test, the writer 
divided the students' problems as follows:

a. Unfamiliarly in Adapting the List of Sub-ordinate Conjunction.

The students at the grade XII of SMA N grade XII Metro were not familiar with the words: "until, till since, as, unless, although, though, after". Even some parts of them students did not even know their level of education.

According to the data from the interview with the students of the grade XII of SMA $\mathrm{N}$ grade XII Metro they had the difficulties in arranging the idea of how to use subordinate conjunction in sentence writing. Beside, the words "until, till, since, as unless, though, although" were hardly used in writing class.

\subsection{Discussion}

In analyzing the data, from the tests and the interview with both the teacher and the students, the writer intended to see how far the students used sub-ordinate conjunction in their sentence writing, and whether they were familiar in using sub-ordinate conjunction. Writing, however, is a way to develop the students' ability in communication either in oral or written form (KTSP curriculum for SMA). Hence, based on the test of the interview in this research, the researcher emphasize on the need of the students' knowledge in writing; as one of four English skills which should be developed.

However, the result of the students' test was not fairy matching with their level of knowledge. The students tended to make their sentence writing as they like. Even the teacher had given the preliminary point of view in making a good sentence and sentences' connector, but they seem to confuse about this. Here, the researcher would not blame this as the teachers in consistency in teaching English. But the researcher saw this as the students' passiveness in learning English, such as they were not familiar with the use of conjunction and the difficulties in adapting it into their writing practice.

Thus, having seen the list of students' tables in making subordinate conjunction, one thing that should be taken in consideration was the students' basic knowledge in building sentences into sentence writing where it should be given top priority.

Nevertheless, the researcher would like to note down on the ideas of Oshima and Hogue (1990:3) that the sentence is a basic unit organization in writing in which a group of related sentences develop only one main ideas. However, after analyzing the students' ability in using sub-ordinate conjunction in sentence writing at the grade XII of SMA N grade XII Metro, the researcher emphasized at the developing of students' ability in writing by using sub-ordinate conjunction. 


\section{Conclusion And Suggestion}

\subsection{Conclusion}

Based on the research findings and discussion earlier, the researcher can conclude as follows:

The used of sub-ordinate conjunction in sentence writing at the grade XII students of SMA N grade XII Metro is rarely used not only on the students' level of knowledge but also on the making a simple sentence writing. The students emphasized their writing without paying attention to the rule of making a good writing.

The result of the students test in using sub-ordinate conjunction in sentence writing proves that the students are framing up to make a sentence into "the longer their sentences, the better their writing" even though they have been asked to make at least ten sentences long. The students seem to ignore the entire rule in making a good sentence in writing, even by using sub-ordinate conjunction. This situation happened by the condition of the students themselves while adapting the writing practice. Moreover, the students were not fully familiar in adapting the list of sub-ordinate conjunction prepared by the researcher while administering the writing test. So, the teacher must be teach the students for learning writing more especially conjunction and used it well in sentence writing. 
1.2 Suggestion

After identifying the above problems, and based on the research finding, the researcher would like to suggest:

1.2.1 Since the used of sub-ordinate conjunction is one of the main factor in making the students have a better writing, the teacher should emphasizes it again and again. Hence, this thing can be done by giving the chance to the students in arranging their sentences before writing into a sentence.

1.2.2 Another attempt for the teacher is asking the students to make brief summary about the use of conjunction in English writing and also its usage for making a good sentence. The teacher can introduce the conjunction as the important thing to make the students' writing flow smoothly by giving the students information of how to write well. It is not by all means to make a good sentence but also to know of the things involved in writing such as sentence connector, preposition, etc. 


\section{REFERENCES}

Algeo, John, Internat. 1998. Flower's Modern English Usage. R.W Burchfield.

Depdikbud. 199grade XII. Kurikulum (GBPP) SMU. Departemen Pendidikan dan Kebudayaan.

Dryer, Matthew S. 2005 Order of Adverbial subordinator and Clause. Oxford University Press.

Finochiaro, Marry and Bonomo, M. 1973. The Foreign Language Learners: A Guide for Teacher. Jakarta: Regent Publishing Company Inc.

Fitriyati, Emilia. 1995. The Correlation between Students' Clause Mastery and Their Ability in Writing Sentence at the Grade XII Students Of SMA Kartini Bandar Lampung. Bandar Lampung: a script unpublished.

Fries, Charles C. 1973. Teaching and Learning English as Foreign Language. Ann Arbor: The University of Michigan Press.

Halliday, M.A.K. 1994. An Introduction to Functional Grammar (2 $2^{\text {nd }}$ edition). Edward Arnld: London
Hermanto. 2005. Increasing the Students' Ability in Using Correlative Conjunction in Sentence Writing at the Second Year Students Of SMA Gajah Mada Way Halim, Bandar Lampung. Bandar Lampung: A Script Unpublished.

Hornby, A. S. 2005. Oxford Advanced Learners' Dictionary of Current English. New York: Oxford University Press.

Lampung University. 1985. Pedoman Penulisan Karya Ilmiah. Bandar Lampung: Lampung University Press.

Lado, Robert. 1972. Language Teaching: A Scientific Approach. New York: Mc Grawhill. Publishing Co.

Leedy, Paul D. 197grade XII. Practical Research; Planning and Design. New York: Mc Milan Publishing Co.

Moleong, Lexy J. 1989. Metodologi Penelitian Kualitatif.

Bandung. Remaja Karya.

Oshima, Alice and Ann Hogue. 1983. Writing Academic English: Writing and Sentence Structure WorkBook for International Students. New York: WesleyPublishing Co.

Siahaan, Sanggam. 2008. The English Sentence. Yogyakarta: Graha Ilmu. 
Siagiyanto, Bambang Eko, (2012), An Analysis of Students' Ability in Using SubOrdinate Conjunction in Paragraph Writing of the First Year Students of SMAN 4 Metro. Unpubished.
Wiener, Harvey S., 1981. The Writing Room. Oxford University Press: Oxford.

Wishon, George E. and Julia M. Burke. 1980. Let's Write English. New York: Litton Educational Publishing, Co. 